INTERNATIONAL JOURNAL OF MULTIDisciplinARY RESEARCH AND ANALYSis

ISSN(print): 2643-9840, ISSN(online): 2643-9875

Volume 04 Issue 07 July 2021

DOI: 10.47191/ijmra/v4-i7-09, Impact Factor: 6.072

Page No.- 924-928

\title{
Village Development with Creativity Based on Local Wisdom in Bali
}

\author{
I Wayan Sugiartana ${ }^{1}$, I G. W. Murjana Yasa ${ }^{2}$ \\ ${ }^{1,2}$ Faculty of Economics and Business, Udayana University, Indonesia
}

ABSTRACT: Creativity in all fields, including in the forms of the creative economy, which always comes up with unique added value, creates extraordinary new "markets", and succeeds in absorbing labor and promising economic income. Creativity can be encouraged to grow and develop by utilizing local wisdom owned by the village, so that it will be an effective instrument in encouraging the development of the socio-cultural and economic fields of rural communities. Support the development of tourist villages. The research method used in this study is a literature review. The results in this study the development of tourism villages based on community creativity and local wisdom is an approach that offers more roles to the community through this potential, it is hoped that the community can develop, the economy increases, the community is prosperous and the poverty in the community can be reduced in number.

KEYWORDS: creativity, tourist village, local wisdom

\section{INTRODUCTION}

The development of tourist travel is marked by the emergence of new motivations and travel patterns carried out by tourists, especially in the market segment of tourists who are experienced (mature market), and those who are educated and have a high level of concern for current issues such as environmental conservation, sustainable tourism, community-based tourism, and local culture. The change in question is the tendency of travel patterns from mass tourism to alternative tourism. Alternative tourism is a form of counterbalance to the rapid development of mass tourism and is seen as less friendly to the environment and less in favour of local communities.

Changes in tourist travel patterns automatically encourage tourist consumption patterns (customer behavior patterns) towards tourism products or tourism destinations that no longer focus on 35 (sun, sea, and sand) or popular tourist destinations, but develop more broadly on various types of activities. tourism that is oriented to the introduction of nature or local culture with the motivation to enrich insight, self-development and self-actualization, with forms of adventure tourism such as hiking, trekking, special interest tourism (bird watching, wild life viewing), cultural tourism and village tourism (tourism village). Tourism villages are internationally known by various terms such as village tourism, rural tourism, farm tourism, or agro tourism (Leu, 1992: 212; Naisbit, 1994: 137; Dolors, 1995: 49; lakovidou, 1995: 87; Oppermann, 1996: 212; Dowling, 1996:220) has been widely implemented in various countries, such as in Switzerland, Kenya, Senegal, Greece, Germany, and Thailand.

The development of a tourism village is an alternative that is considered very strategic to answer a number of global and national issues related to tourism such as environmental conservation, sustainable tourism, community-based tourism, community, and local culture. According to the Ministry of Tourism and Creative Economy (2016: 7) the value of the benefits that can be achieved from the development of tourist villages are: one, through the development of tourist villages, a tourism destination will have a diversity or product diversification that will open up opportunities for repeat visits for tourists who have visited the area or destination. Such; two, the development of tourist villages is also considered to be able to minimize the potential for urbanization of the community from rural to urban areas because it is able to create economic activity in rural areas based on tourism activities (tourism economy).

The productive power of local potential, including the potentials of rural areas, will be encouraged to grow and develop by utilizing the resources owned by the village, so that it will become an effective instrument in encouraging the development of the socio-cultural and economic fields of rural communities; three, further efforts will be encouraged to preserve and empower the unique potential in the form of local culture and local wisdom values that exist in communities that tend to experience the threat of extinction due to the very intense flow of globalization and has entered rural areas. Preservation of cultural resources, 


\section{Village Development with Creativity Based on Local Wisdom in Bali}

local wisdom and rural natural resources (eg landscapes, rice fields, rivers, lakes) which will significantly help reduce global warming.

Efforts to develop alternative tourism in the form of tourist villages in accordance with village characteristics are the right step in anticipating an increase in tourist visits and in general local culture has high values, both philosophical and sociological values. It can be said that local culture is something exotic. The word exotic is defined as something foreign, or not yet known to many people so as to stimulate curiosity (Spillane 1994). Natural beauty, social life, spiritual wealth are attractions that can invite curiosity from outsiders. Therefore, this exoticism must be displayed in authenticity so that it becomes the main attraction in tourist destinations. To preserve the value of local wisdom in tourist areas, it must involve community participation through community-based tourism activities. This can be done by building community groups that are active and concerned about the conservation of tourist areas.

The form of local wisdom is in the lives of people who know their environment well, people live side by side with nature in harmony, understand how to use natural resources wisely and wisely. Local wisdom in the form of natural resource and environmental management is a form of community conservation. Haryati Subadio in Brata (2016), said that local wisdom (local genius) as a whole includes, maybe even can be considered the same as cultural identity which can be interpreted as the cultural identity or personality of a nation. Local wisdom is a local culture that is owned by certain communities and in certain places that are able to survive in the face of globalization, because the local wisdom contains values that can be used as a means of building national character (Yunus, 2013). So, local wisdom is the truth that has become a tradition or is permanent in an area. Local wisdom has a high life value and deserves to be explored, developed, and preserved as an antithesis or socio-cultural change and modernization

According to Pattinama (2009) asserts that the emergence of local wisdom can help local communities overcome their problems through the potential that exists in the community and can be developed, through this potential it is hoped that the community can develop, the economy will increase, the community will prosper and the poverty that exists in the community can be reduced. to increase the competitiveness of tourist areas. Tourists can enjoy the tourist attractions of the village more optimally, which in turn will have an economic impact on the community. Forms of creativity that can be developed include managing homestays and serving local food and drinks for tourists who come. This is important because homestays are the main choice for tourists who want to stay in tourist villages and creativity in processing and serving local food and drinks will further complement the travel experience. Apart from that, subak can also be used as economic creativity, such as how to plant rice, plow rice fields, including picking agricultural products directly such as vegetables for tourists who want to get a different experience. The problem faced by partners is the lack of knowledge in the management and processing and presentation of food, local drinks and others. Creativity in the processing of food, beverages and the potential of subak can grow the creative economy in tourist villages. The creative economy and the tourism sector are two things that influence each other and can synergize with each other if managed properly to improve the welfare of the community.

\section{METHOD}

This research method uses a literature review. Literature review contains reviews, summaries, and the author's thoughts on several library sources (articles, books, slides, information from the internet, etc.) about the topics discussed, a good literature review must be relevant, up-to-date, and adequate.

\section{RESULT AND DISCUSSION}

\section{Community Based Tourism Development}

One of the discourses that is currently re-warming is about community-based tourism development (tourism-based community development). Community-based tourism development is different from conventional tourism development. In conventional development, policies in the field of tourism development use a top-down system, namely using a centralized approach, while community-based tourism development uses a bottom-up approach or emphasizes a bottom-up system. Community-based tourism development is a theory that emphasizes the people's economy and people's empowerment. This theory is used as a reaction to the failure of modernization that has been applied so far in developing countries. Top-down policy making is considered to have forgotten the basic nature of development itself so that the people are not increasing their quality of life, but are actually disadvantaged and tend to be marginalized in their own environment (Pitana, 1999: 75).

Thus, the main key to development (Natori, 2001) is the balance and harmony between the environment, resources, and tourist satisfaction created by the will of the community itself. These three factors are priorities for the sustainability of social, cultural and economic systems. According to Erawan (2003), community-based tourism has the characteristics of a small scale, owned by members/groups of the local community so as to provide benefits to the local community, provide job 


\section{Village Development with Creativity Based on Local Wisdom in Bali}

opportunities and economic opportunities to the local economy, spread out locations and not concentrated in one place, designs and activities reflect the character of the local area, prioritize the preservation of cultural heritage (culture heritage), do not turn off industries and other activities that are complementary, offer quality experiences to tourists, and are profitable business activities.

The theory of community-based tourism development is considered as the opposite of the conventional theory which emphasizes development, namely starting from the bottom (bottom-up). In this condition, a social learning process will occur so that the local community is required to be involved in various stages of development. Thus the management of development is really carried out by those whose lives and lives are influenced by the development itself (Pitana, 1999: 76).

Furthermore, Natori (2001:6) in his book A Guidebook for Tourism-Based Community Development, distinguishes conventional tourism development from people-based tourism development. In the conventional tourism development model, the interaction between resources, residents, and visitors is not balanced, causing conflict. However, in the people-based tourism development model, resources, local residents, and visitors interact harmoniously, in addition to making the community a key player in tourism development.

\section{The Role of Creativity and Local Wisdom in Tourism Village Development}

The tourism village is one example of alternative tourism development that aims to build sustainable villages in the tourism sector. This tourism development is influenced by people's lifestyles, economic, physical, and social conditions of the rural areas such as cultural heritage, agricultural activities, landscapes, as well as history and culture. Thus, tourism village modeling must continue and creatively develop regional identities or characteristics. The development of rural tourism is driven by three factors. First, rural areas have natural and cultural potentials that are relatively more authentic than urban areas, rural communities still carry out cultural and topographical traditions and rituals that are quite harmonious. Second, rural areas have relatively pristine physical environments or have not been heavily polluted by various types of pollution compared to urban areas. Third, at a certain level, rural areas face relatively slow economic development, so that optimal utilization of the economic, social and cultural potential of local communities is a rational reason for developing rural tourism (Damanik, 2013: 69).

Locally-based tourism village management requires the care and participation of the community itself to always innovate and be creative in developing the village area which is used as a tourist village. According to Cohen and Uphoff (1979) the role or participation carried out by the community can be seen from the stages of planning, implementation, management or utilization, monitoring, enjoying the results and evaluation. The development of this tourist village must pay attention to the ability and level of acceptance of the local community which will be developed into a tourist village. This is intended to determine the character and abilities of the community that can be utilized in the development of tourist villages, determine the type and level of community empowerment appropriately.

Creativity is needed to increase the competitiveness of tourist areas. Tourists can enjoy the tourist attractions of the tourist village more optimally, which in turn will have an economic impact on the community. Forms of creativity that can be developed include managing homestays and serving local food and drinks for tourists who come. This is important because homestays are the main choice for tourists who want to stay in Tourism Villages and creativity in processing and serving local food and drinks will further complement the travel experience. The problem faced by partners is the lack of knowledge in managing homestays and processing and serving food and beverages. local. Creativity in food and beverage processing can foster a creative economy in tourist villages. The creative economy and the tourism sector are two things that influence each other and can synergize with each other if managed properly (Ooi, 2006).

Local people are very familiar with local wisdom because that is where local wisdom develops and appears for the first time, the emergence of habits begins when they have to work outside the home and need the help of others to complete the work. Clearing land for farming and planting rice in the fields is one example, this is one example of how these habits emerged and became traditions so that local wisdom emerged. Local wisdom exists because there are habits that produce an action that creates an attitude in dealing with these events and then causes a variety of expressions, one of which is traditional customs, works of art to the way of human thinking so as to form a local wisdom (Azizah, 2017: 68), because the community has known the local wisdom for a long time so that they have used habits for generations to produce something in fulfilling their lives, but it all depends on the local community itself because it all depends on how they behave and behave.

In modern times, local wisdom can be trusted to have a good impact on the unity of community life, with the unification of all elements in society, it will be very easy for people to voice inspiration, ideas and even ideas that can help people solve problems in their lives, one of which is how to solve problems. their economy can be overcome, establish a good neighborly life to 


\section{Village Development with Creativity Based on Local Wisdom in Bali}

maintain cohesiveness at work, all of this is created because of the existence of mutual need bonds in the community (Sopa, 2018).

Local wisdom is a sign of how people live their lives and get life experiences and all of that is applied in their daily lives and becomes a way of life in society in acting and making decisions. (Pattinama, 2009) emphasizes that the emergence of local wisdom can help local communities overcome their problems through the potential that exists in the community and can be developed, through this potential it is hoped that the community can develop, the economy will increase, the community will prosper and poverty in the community can be reduced in number, all of that This can happen because in the lives of local people the value of traditional life can form an equal life between humans and nature, but all that happens is inseparable from the lifestyle and needs of the community itself.

Tourism development must be based on conditions and carrying capacity with the aim of creating mutually beneficial long-term interactions between the achievement of tourism development goals, increasing the welfare of local communities, and sustainable environmental carrying capacity in the future (Fandeli, 1995). This is done by developing attractiveness, accessibility, and facilities that support recreation, tourists and local residents benefit from each other. Tourism development must be based on conditions and carrying capacity with the aim of creating mutually beneficial long-term interactions between the achievement of tourism development goals, increasing the welfare of local communities, and sustainable environmental carrying capacity in the future (Fandeli, 1995). In the management and development of tourism objects, a complete method and data analysis is needed so that the implementation of this planned program can be achieved and right on target. The method used in developing the potential of a tourist village is the $4 \mathrm{~A}$ method, namely attractions, accessibility, amenities, and activities.

\section{Subak's creativity as an attraction}

Subak is a customary law community organization, in the form of an association of farmers who manage irrigation water in paddy fields, and has socio-agrarian-religious characteristics (Windia, 2006). The uniqueness of subak culture which has elements of mutual cooperation and the concept of Tri Hita Karana makes UNESCO recognize subak as a world cultural heritage in the 36th general assembly in St. Petersburg, Russia. On the other hand, the existence of subak has decreased due to the conversion of agricultural land to non-agriculture. The Badung Agriculture Service stated that from 2008 to 2014,160 ha of wetlands had been converted into tourist accommodation and residential development. Locations with the most land conversion occurred in three sub-districts, namely North Kuta District reaching 94 ha, Mengwi 33 ha, and Abiansemal 4 ha. One of the efforts made to maintain the existence of subak as a cultural heritage is to see the potential of subak as a tourist attraction. Agrotourism is one form of placing the primary sector (agriculture) into the tertiary sector (tourism). In general, the concept of agro-tourism contains the notion of a tour guide or trip combined with aspects of agricultural activities (Windia et al, 2013).

\section{CONCLUSION}

The tourism village in its development is a process of extracting the potential that exists in the village whether it comes from natural, social, cultural, community or other elements, so that the natural nature and preservation of village characteristics are maintained and maintained. The community as the subject and object of village development must always be involved in the whole process of developing a tourist village, bearing in mind that the purpose of developing a tourist village is not only to develop characteristics, traditional and cultural values into a tourist attraction, but also to improve the welfare of the community, so that the community must play a role and be the beneficiary. The development of a tourism village based on community creativity and local wisdom is an approach that offers more roles for the community to be involved in the whole process of developing a tourist village.

\section{REFERENCES}

1) Alfian, Magdalia. (2013). Potensi Kearifan lokal dalam Pembentukan Jati Diri dan Karakter Bangsa. Prosiding The 5 thn ICSSIS; "Ethnicity and Globalization", di Jogyakarta pada tanggal 13-14 Juni 2013

2) Azizah, S.N. 2017. Pengembangan Ekonomi Kreatif Berbasis Kearifan Lokal Pandanus Handicraft dalam Menghadapi Pasar Modern Perspektif Ekonomi Syariah. Study Case di Pandanus Nusa Sambisari Yogyakarta, 17, 63-78.

3) Brata. 2016. Kearifan Budaya Lokal Perekat Identitas Bangsa. Jurnal Bakti Saraswati, 5 (1), 11

4) Busro, Muhammad. 2018. Teori-teori Manajemen Sumber Daya Manusia. Jakarta: Prenadamedia Grup.

5) Cohen, E., \& Uphoff. (1974). Who is a Tourist? A Conceptual Clarification. Sociological Review, 22(4), 527-555

6) Damanik., Juniaanton., \& Helmut, F. W. (2006). Perencanaan Ekowisata: Dari Teori ke Aplikasi. Yogyakarta: Andi Offset. 


\section{Village Development with Creativity Based on Local Wisdom in Bali}

7) Fajarini,Ulfah. 2014. Peranan Kearifan Lokal Dalam Pendidikan Karakter. Jurnal Sosio Didaktika; Vol.1, No.2. (http://journal. uinjkt ,ac,id / SOSIOFITK/ article/viewFile/1225/1093)

8) Garna, Judistira K. 2001. Ilmu-Ilmu Sosial Dasar-Konsep-Posisi. Bandung: Pascasarjana Unpad

9) Gonner, dkk. 2007. Menuju Kesejahteraan (Pemantauan Kemiskinan di Kutai Barat, Indonesia). Bogor: Center for International Forestry Research (CIFOR).

10) Hasibuan, Malayu S.P. 2012. Manajemen Sumber Daya Manusia. Edisi Revisi. Jakarta: PT. Bumi Aksara.

11) Istiawati, F.N. 2016. Pendidikan Karakter Berbasis Nilai-Nilai Kearifan Lokal Adat Ammatoa dalam Menumbuhkan Karakter Konservasi. Cendikia, 10(1): 1-18.

12) Kartasasmita, Ginanjar. 1997. Pemberdayaan Masyarakat. Bandung: Penerbit Alumni.

13) Kamonthip, K. (2007). Local Wisdom, Environmental Protection And Community Development: The Clam Farmers In Tambon Bangkhunsai, Phetchaburi Province, Thailand. MANUSYA: Journal of Humanities, 10 (1), 1-10.

14) Labolo, Muhammad. 2011. Memahami Ilmu Pemerintahan. Jakarta: PT Raja Grapindo Persada

15) Miharja, Deni. 2013. Adat, Budaya dan Agama Lokal (Studi Gerakan Ajeg Bali Agama Hindu Bali). Jurnal Studi Agama dan Pemikiran Islam. 7(1). Pp. 53-78.

16) Pattinama, M. J. 2009. Pengentasan Kemiskinan Dengan Kearifan Lokal (Studi Kasus Di Pulau Buru Maluku Dan SuradeJawa Barat). Makara, Sosial Humaniora, 13 (1), 1-12.

17) Prijono, S. dan Pranarka. 2005. Pemberdayaan: Konsep, Kebijakan dan Implementasi. Jakarta: CSIS.

18) Ratna, N. K. (2011). Antropologi Sastra. Yogyakarta: Pustaka Pelajar

19) Rosmaladewi, Okke. 2018. Manajemen Kemitraan Multistakeholder Dalam Pemberdayaan Masyarakat. Yogyakarta: Grup Penerbit CV. Budi Utama.

20) Sopa, M. 2018. Local Wisdom in the Cultural Symbol of Indonesian Traditional House, 524-531. http://doi. org/10.18502/kss.v3i4.1962

21) Sungkharat, U. 2010. Local Wisdom: The Development Of Community Culture And Production Processes In Thailand. International Business and Economics Research Journal, 9(11), 115-120.

22) Utama, D.K.M.B. 2013. Kearifan Lokal dan Lingkungan. PT. Gading Inti Prima dan Pusat Penelitian dan Pengembangan Kebudayaan, Kementerian Pendidikan dan Kebudayaan RI.

23) Wibowo, Agus. 2015. Pendidikan Karakter Berbasis Kearifan Lokal di Sekolah. Yogyakarta: Pustaka Pelajar

24) Yunus, Rasid. 2013. Transformasi Nilai-Nilai Budaya Lokal Sebagai Upaya Pembangunan Karakter Bangsa. Jurnal Penelitian Pendidikan LPPM Universitas Indonesia, 13 (1), 67-68. 